\title{
Prevalence of Dermatitis and Superficial Fungal Infection of the Hands in Seafood Workers: An Investigation from Food Markets in Ningbo, China
}

This article was published in the following Dove Press journal: Risk Management and Healthcare Policy

\author{
Feng Le ${ }^{1,2}$ \\ Bin $\mathrm{Liu}^{2}$ \\ Zixiang $\mathrm{Si}^{3}$ \\ Sheng $\mathrm{Li}^{1}$ \\ Jianjun Qiao (1D) \\ 'Department of Dermatology, The First \\ Affiliated Hospital, Zhejiang University \\ School of Medicine, Hangzhou, People's \\ Republic of China; ${ }^{2}$ Department of \\ Dermatology, Beilun Traditional Chinese \\ Medicine Hospital, Ningbo, People's \\ Republic of China; ${ }^{3}$ Department of \\ Dermatology, Beilun Branch of the First \\ Affiliated Hospital, Zhejiang University \\ School of Medicine, Ningbo, People's \\ Republic of China
}

Correspondence: Jianjun Qiao Department of Dermatology, The First Affiliated Hospital, Zhejiang University School of Medicine, No. 79, Qingchun Road, Hangzhou 310003, People's Republic of China

Email qiaojianjun@zju.edu.cn
Objective: Seafood workers have high risks of hand skin diseases. The purpose of this survey is to study the prevalence of occupational hand skin diseases in this population.

Methods: From March 2018 to October 2018, seafood workers in two food markets in Ningbo, China were investigated. Fungal microscopy and cultures from lesions on the hands and nails were performed. A community-based investigation of hand skin diseases was performed as a control group.

Results: One handred and eleven of $135(82.2 \%)$ seafood workers in two food markets in Ningbo were taken into the investigation. The prevalence of hand dermatitis was $50.5 \%$ (56/ $111)$ in seafood workers, which is significantly higher than that of the control group $(7.43 \%$, $p<0.001)$. It was found that the incidence of superficial fungal infection of the hands in seafood workers was much higher than that in community residents $(26.1 \%$ vs $2.7 \%$, $p<0.001)$. Without wearing waterproof gloves, longer working time per day, longer history of seafood work increased the risk of hand dermatitis, instead of candidial infection of the hands and nails.

Conclusion: Hand skin diseases are highly prevalent in seafood workers in Ningbo, a city in eastern China. This public health problem should be addressed in this population.

Keywords: seafood, hand dermatitis, fungal colonization, Candida

\section{Introduction}

Skin diseases are one of the most common occupational diseases. ${ }^{1}$ According to the Health and Safety Enforcement Agency, there are approximately 16,000 cases per year of work-related dermatitis in China, ${ }^{2}$ and 4 million working days are lost due to occupational skin diseases in the UK every year. ${ }^{3}$ In 2010 , there were 850,000 cases of workrelated dermatitis among workers in the US. ${ }^{2,4}$ Contact dermatitis account for $70-90 \%$ of hand dermatosis, which is a common occupational cutaneous diseases. ${ }^{1,3,5-11}$

It has reported that hand dermatitis and fungal infections may be caused by prolonged exposure to water and gloves. ${ }^{10,12}$ The prevalence rate of contact dermatitis was reported to be $8-11 \%$ in fishermen and the incidence of hand itching was $49.6 \% .^{10}$ As hands are frequently exposed to water and occlusive gloves, the risk of hand dermatitis and fungal infection is estimated to be high for seafood workers. ${ }^{10,12}$ However, there are limited epidemiological data concerning hand dermatitis and fungal infection in seafood workers.

In the coastal cities of China, seafood is one of the main food sources for people, ${ }^{13}$ particularly for residents of Ningbo. ${ }^{14}$ Ningbo ranks first in per capita seafood 
consumption in China. ${ }^{15}$ The number of people employed in the seafood industry is growing rapidly. China has more than 14 million seafood practitioners. ${ }^{16}$ There are 786,900 seafood practitioners in Zhejiang Province. ${ }^{16}$ To analyze the prevalence of hand skin diseases in seafood workers, we conducted a cross-sectional survey in two representative seafood markets in Ningbo, Zhejiang Province, China.

\section{Methods}

\section{Study Design}

A cross-sectional survey was conducted from March to October 2018 to investigate dermatitis and hand fungal infection in seafood workers in two seafood markets in Ningbo, China. In this survey, seafood workers were defined persons who engage in seafood transportation, storage, and sales in seafood markets. During daily work, seafood workers are in contact with seafood with or without wearing waterproof gloves. To serve as a control, a survey of 148 residents from the community where the two vegetable markets were located was conducted concurrently. The study was approved by the ethics committee of the Beilun Traditional Chinese Medicine Hospital, Ningbo, China (8 March 2018; Approval number 2018-007). All participants provided written informed consent.

\section{Questionnaire and Data Collection}

A questionnaire was designed for this survey. The questionnaire included demographic characteristics (gender, age, work experience), pertinent medical history (history of cutaneous diseases and treatment, complicated with chronic systemic diseases), glove-wearing behavior, and types of hand skin lesions.

To test the usablity of the questionnaire, it was completed by three investigators (FL, BL and ZS), who then reached a consensus on how to implement the questionnaire. In order to ensure the feasibility and utility of the questionnaire, prior to formal data collection, a pre-survey was carried out on $2 \%$ of the sample from the two food markets. Data obtained from the questionnaires were recorded by two investigators (FL and ZS) after careful inquiry and examination. Two investigators (FL and JQ) analyzed the data. The hands of seafood workers and residents were examined and diagnosed by two investigators (FL and ZS). Hand dermatitis was defined as in previous studies. ${ }^{5,9,12}$ We examined lesions on the hands, including erythema, plaques, papules, edema, blisters, scales, fissures, and ulcers. Nail changes were also detected. Symptoms, cutaneous eruptions and nail changes were recorded on the survey form. During examination, photographs of hands were taken to record the signs of the hand skin rash.

\section{Fungal Microscopy, Culture and Identification}

Skin lesions on the hands or nails were scraped and observed under microscopy. Only when hyphae or pseudohyphae was detected, a diagnosis of fungal infection was made. Clinical samples taken from the hands were inoculated in potato dextrose agar medium for fungal culture at $26^{\circ} \mathrm{C}$. DNA extracted from the cultures was sequenced. Polymerase chain reaction products of rDNA-ITS were sequenced to identify pathogens to the species level.

\section{Statistical Analysis}

SPSS 21.0 (IBM, Inc. Armonk, NY) was used for statistical analysis. Counting data were expressed as rate (\%) and chi-squared test or Fisher's exact test was used for comparison between groups. Measured data were expressed as mean \pm standard deviation. Comparison between groups was analyzed by student's $t$ test.

\section{Results}

A total of 111 of 135 seafood workers (response rate: $82.2 \%$ ) in 2 of 8 seafood markets in our investigation area were surveyed. For the control group, 186 residents were approached and 148 participated (response rate: $80 \%$ ) (Table 1). Before the seafood workers were engaged in this work, there were no significant differences between them and the community population in the history of hand contact dermatitis and hand superficial mycosis (Table 1).

The incidence of hand dermatitis and superficial fungal infection in seafood worker group was much higher than those in the control group (Table 2). The clinical characteristics of hand dermatitis and fungal infection in seafood workers are listed in Table 2. Fungi isolated from cutaneous lesions of hands and nails are listed in Table 3.

We also compared the seafood workers with and without dermatitis and fungal infection of the hands. Wearing waterproof gloves, working time span, and seafood types were not related to the incidence of the diseases (Table 4). Without wearing waterproof gloves, long working time per day $(>4 \mathrm{~h})$, and longer history of seafood work ( $>20$ years) were associated with risk of hand dermatitis. Wearing gloves and working time were not associated with risk of fungal infection of the hands. Furthermore, 
Table I Demographic Characteristics and Medical History of Seafood Workers in Two Food Markets and Community Residents in Ningbo, China

\begin{tabular}{|c|c|c|c|}
\hline & $\begin{array}{l}\text { Seafood } \\
\text { Workers } \\
(n=I I I) \text { n (\%) }\end{array}$ & $\begin{array}{l}\text { Community } \\
\text { Residents Control } \\
(n=\mid 48) n(\%)\end{array}$ & P value \\
\hline $\begin{array}{l}\text { Age (Mean } \pm \\
\text { SD) }\end{array}$ & $57.3 \pm 19.4$ & $53.6 \pm 9.0$ & 0.043 \\
\hline Female & $63(56.8)$ & $96(64.9)$ & 0.185 \\
\hline $\begin{array}{l}\text { Wet work } \\
\text { environment }\end{array}$ & III (I00.0) & $7(4.7)$ & $<0.001$ \\
\hline $\begin{array}{l}\text { History of } \\
\text { hand skin } \\
\text { diseases }\end{array}$ & $4(3.6)$ & II (7.4) & 0.192 \\
\hline $\begin{array}{l}\text { History of } \\
\text { tinea manus/ } \\
\text { onychomycosis }\end{array}$ & $6(5.4)$ & $4(2.7)$ & 0.429 \\
\hline $\begin{array}{l}\text { Response rate } \\
\text { to the survey }\end{array}$ & $111 / 132$ (82.2) & $148 / 186(80)$ & 0.307 \\
\hline $\begin{array}{l}\text { Hand } \\
\text { dermatitis }\end{array}$ & $56(50.5)$ & II (7.4) & $<0.001$ \\
\hline $\begin{array}{l}\text { Hand fungal } \\
\text { infection }\end{array}$ & $29(26.1)$ & $4(2.7)$ & $<0.001$ \\
\hline $\begin{array}{l}\text { Only involving } \\
\text { the hand skin } \\
\text { Involving the } \\
\text { Nails }\end{array}$ & $\begin{array}{l}9(8.1) \\
20(18.0)\end{array}$ & $\begin{array}{l}2(1.4) \\
2(1.4)\end{array}$ & $\begin{array}{l}0.022 \\
<0.001\end{array}$ \\
\hline
\end{tabular}

Table 2 Clinical Features of Hand Dermatitis and Hand Superficial Fungal Infection in Two Food Markets in Ningbo, China

\begin{tabular}{|l|l|l|}
\hline & $\begin{array}{l}\text { Hand Dermatitis } \\
(\mathbf{n = 5 6 )} \mathbf{n}(\%)\end{array}$ & $\begin{array}{l}\text { Hand Superficial } \\
\text { Fungal Infection } \\
(\mathbf{n}=29) \mathbf{n} \text { (\%) }\end{array}$ \\
\hline $\begin{array}{l}\text { Sites of Cutaneous } \\
\text { Lesions }\end{array}$ & & \\
Palmar/dorsal of the hands & $39(69.6)$ & $\mathrm{II}(37.9)$ \\
Interdigital & $29(51.8)$ & $21(72.4)$ \\
Nails & $26(46.4)$ & $20(69.0)$ \\
\hline Lesion Type & & \\
Erythema & $24(42.9)$ & $\mathrm{I}(3.5)$ \\
Scale & $36(64.3)$ & $3(10.3)$ \\
Erosion & $17(30.4)$ & $17(58.6)$ \\
Maceration & $29(51.8)$ & $20(69.0)$ \\
\hline
\end{tabular}

we found that when they were attacked by cutaneous diseases of the hands, they did not seek medical treatment in a timely fashion (Table 4).
Table 3 Fungal Isolates from the Hands and Nails in Seafood Workers in Two Food Markets in Ningbo, China

\begin{tabular}{|l|l|}
\hline Isolates & Number (\%) \\
\hline Candida albicans & $15(46.8)$ \\
Candida parapsilosis & $3(9.3)$ \\
Candida guilliermondii & $2(6.2)$ \\
Candida glabrata & $2(6.2)$ \\
Candida krusei & $1(3.1)$ \\
Other yeasts & $8(25.0)$ \\
Total & $31(100)$ \\
\hline
\end{tabular}

\section{Discussion}

Wet-work is defined as immersing hands in liquids for more than 2 hours per working day, wearing waterproof gloves for more than 2 hours per working day, or washing hands $>20$ times per working day. ${ }^{17}$ The risk of hand skin diseases is increasing in wet workers. ${ }^{17}$ Various occupations have high exposure to liquids, including nurses, hairdressers, food handlers, florists, cooks and chefs, car mechanics, and a number of high-risk occupational groups. ${ }^{17}$ The incidence of hand dermatitis varies according to the work type and wet work time per shift. ${ }^{11,12,17-19}$ Seafood workers are exposed to water and seafood in their daily work. In the present epidemiological study, we found that the incidence of hand dermatitis was as high as $50.5 \%$ in seafood workers in a typical coastal city, Ningbo, China.

The incidence of fungal infection of the hands and nails was also much higher in seafood workers than those of the general population in our survey. The warm and humid climate in eastern China provides favorable conditions for yeast growth. High incidence of hand candidial infection may be associated with high temperatures while wearing the gloves and soaking hands in water. The local micro-environment of the hands of seafood workers may cause overgrowth of Candida and other yeasts in the hand microbiota.

Touching seafood with hands or wearing waterproof gloves are both wet risk factors for hand dermatitis and superficial fungal infection of the hands. We compared seafood workers with and without dermatitis and fungal infection; there were no significant differences among the age, sex, seafood type, and water type. Long time exposure to water may cause maceration and erosion the hand skin. In the survey, we found that wearing waterproof gloves, longer working time per day, and longer history of seafood work are high risk for hand dermatitis, instead of superficial fungal infection of the hands. Wet environment whether in the water or in the gloves are risk factors for candida growth, this can explain the similar rates of fungal infection of the hands in the two subgroups 
Table 4 Comparison of Seafood Workers with and Without Hand Dermatitis and Hand Superficial Fungal Infection in Two Food Markets in Ningbo, China

\begin{tabular}{|c|c|c|c|c|c|c|}
\hline & $\begin{array}{l}\text { With Hand } \\
\text { Dermatitis } \\
(n=56) n(\%)\end{array}$ & $\begin{array}{l}\text { Without Hand } \\
\text { Dermatitis }(n=55) \\
\text { n (\%) }\end{array}$ & $\mathbf{P}$ value & $\begin{array}{l}\text { With Fungal } \\
\text { Infection }(n=29) \\
n(\%)\end{array}$ & $\begin{array}{l}\text { Without Fungal } \\
\text { Infection }(n=82) \\
n(\%)\end{array}$ & $P$ value \\
\hline Age (Mean \pm SD) & $53.7 \pm 8.2$ & $53.5 \pm 9.9$ & 0.889 & $57.8 \pm 6.8$ & $52.1 \pm 9.3$ & 0.001 \\
\hline Female & $36(64.3)$ & $27(49.1)$ & 0.106 & $12(41.4)$ & $51(62.2)$ & 0.052 \\
\hline Wearing waterproof gloves & $30(58.9)$ & $4 \mid(74.5)$ & 0.021 & $20(69.0)$ & $54(65.9)$ & 0.760 \\
\hline $\begin{array}{l}\text { Seafood Type } \\
\text { Ice fresh } \\
\text { Fresh } \\
\text { Ice fresh+Fresh }\end{array}$ & $\begin{array}{l}23(4 I . I) \\
3 I(55.4) \\
2(3.5)\end{array}$ & $\begin{array}{l}22(40.0) \\
32(58.2) \\
I(1.8)\end{array}$ & $\begin{array}{l}0.980 \\
0.764 \\
0.987\end{array}$ & $\begin{array}{l}9(31.0) \\
19(65.5) \\
1(3.5)\end{array}$ & $\begin{array}{l}36(43.9) \\
44(53.7) \\
2(2.4)\end{array}$ & $\begin{array}{l}0.225 \\
0.268 \\
1.000\end{array}$ \\
\hline $\begin{array}{l}\text { Water Type } \\
\text { Fresh water } \\
\text { Seawater }\end{array}$ & $\begin{array}{l}13(23.2) \\
43(76.8)\end{array}$ & $\begin{array}{l}14(25.5) \\
4 \mid(74.5)\end{array}$ & $\begin{array}{l}0.783 \\
0.783\end{array}$ & $\begin{array}{l}8(27.6) \\
21(72.4)\end{array}$ & $\begin{array}{l}19(23.2) \\
63(76.8)\end{array}$ & $\begin{array}{l}0.634 \\
0.634\end{array}$ \\
\hline $\begin{array}{l}\text { Period of Working (years) } \\
\quad<10 \\
10-19 \\
20-30\end{array}$ & $\begin{array}{l}6(10.7) \\
15(26.8) \\
35(62.5)\end{array}$ & $\begin{array}{l}14(25.5) \\
19(34.5) \\
22(40.0)\end{array}$ & $\begin{array}{l}0.043 \\
0.375 \\
0.018\end{array}$ & $\begin{array}{l}5(17.2) \\
9(31.0) \\
15(51.7)\end{array}$ & $\begin{array}{l}14(17.1) \\
24(29.3) \\
44(53.7)\end{array}$ & $\begin{array}{l}0.790 \\
0.858 \\
0.858\end{array}$ \\
\hline $\begin{array}{l}\text { Daily Working Time (hours) } \\
\qquad 4 \\
4-8 \\
>8\end{array}$ & $\begin{array}{l}0 \\
14(25.0) \\
42(75.0)\end{array}$ & $\begin{array}{l}3(5.5) \\
28(50.9) \\
24(43.6)\end{array}$ & $\begin{array}{l}0.235 \\
0.005 \\
0.001\end{array}$ & $\begin{array}{l}0 \\
10(34.5) \\
19(65.5)\end{array}$ & $\begin{array}{l}3(3.7) \\
32(39.0) \\
47(57.3)\end{array}$ & $\begin{array}{l}0.566 \\
0.665 \\
0.439\end{array}$ \\
\hline
\end{tabular}

of seafood workers (with vs without wearing waterproof gloves, longer working time per day, and longer history of seafood work).

This study contributes evidence of hand skin diseases in seafood workers in a local city in China. However, there are few limitations in the study. First, this study was conducted as cross-sectional study. We could not exclude influence of climate on the incidence of hand skin diseases. Secondly, our study was based on seafood worker-report, clinical examination, and fungal examination. The diagnosis of hand dermatitis is clinical based, instead of based on patch tests. Finally, the sample size and the number of sites are not large, both of which could contribute to selection bias and low statistical power.

In conclusion, our study showed that hand skin diseases, hand dermatitis, and candidial infection of the hands and nails are highly prevalent in seafood workers in Ningbo, China. The data may be useful for controlling hand skin diseases of this specific population.

\section{Author Contributions}

Formal analysis, FL, BL, ZS, SL and JQ; Investigation, FL, BL and ZS; Methodology, FL and JQ; Resources, FL, BL, ZS, SL and JQ; Writing - original draft, FL; Writing - review \& editing, SL and JQ. All authors contributed to data analysis, drafting or revising the article, gave final approval of the version to be published, and agree to be accountable for all aspects of the work.

\section{Funding}

This research was funded by the National Natural Science Foundation of China (81571969 to JQ).

\section{Disclosure}

The authors declare that the research was conducted in the absence of any commercial or financial relationships that could be construed as a potential conflict of interest.

\section{References}

1. Holness DL. Occupational dermatosis. Curr Allergy Asthma Rep. 2019;19(9):42. doi:10.1007/s11882-019-0870-6

2. Shop Uo. Distributive and allied workers: work-related skin disease; July 2010. Available from: https://www.usdaw.org.uk/USDAW/media/ Documents/Health\%20and\%20Safety/Health\%20and\%20Safety\% 20A-Z/Dermatitis.pdf. Accessed April 29, 2020.

3. Papadatou Z, Williams H, Cooper K. Effectiveness of interventions for preventing occupational irritant hand dermatitis: a quantitative systematic review. JBI Database System Rev Implement Rep. 2018;16 (6):1398-1417. doi:10.11124/JBISRIR-2017-003405

4. Ontario PH. Occupational dermatitis in health care settings; September 27, 2017. Available from: https://neo.ipaccanada.org/photos/custom/ Presentations/Occupational\%20Dermatitis.pdf.Accessed April 29, 2020. 
5. Sakhvidi MJZ, Loukzadeh Z, Tezerjani HD. Occupational hand dermatitis in car repair workers. AIMS Public Health. 2019;6 (4):577-586. doi:10.3934/publichealth.2019.4.577

6. Braun R, Dotterud LK. Occupational skin diseases from 1997 to 2004 at the Department of Dermatology, University Hospital of Northern Norway (UNN): an investigation into the course and treatment of occupational skin disease 10-15 years after first consultations with a dermatologist. Int J Circumpolar Health. 2016;75:30100.

7. Mahler V, Aalto-Korte K, Alfonso JH, et al. Occupational skin diseases: actual state analysis of patient management pathways in 28 European countries. J Eur Acad Dermatol Venereol. 2017;31 (Suppl 4):12-30. doi:10.1111/jdv.14316

8. Smith D, Atkinson R, Minai J, Yamagata Z. Occupational skin diseases in nursing. Aust Nurs J. 2002;9(11):19-21.

9. Lampel HP, Powell HB. Occupational and hand dermatitis: a practical approach. Clin Rev Allergy Immunol. 2019;56(1):60-71. doi:10.1007/s12016-018-8706-z

10. Lovreglio P, Rotondi R, Chiarappa P, et al. Applicability of the nordic occupational skin questionnaire for screening contact dermatological disorders in sea fishers. Int J Environ Res Public Health. 2018;15:2. doi:10.3390/ijerph15020381

11. Hamnerius N, Svedman C, Bergendorff O, Bjork J, Bruze M, Ponten A. Wet work exposure and hand eczema among healthcare workers: a cross-sectional study. $\mathrm{Br} J$ Dermatol. 2018;178 (2):452-461. doi:10.1111/bjd.15813
12. Lund T, Petersen SB, Flachs EM, Ebbehoj NE, Bonde JP, Agner T. Risk of work-related hand eczema in relation to wet work exposure. Scand J Work Environ Health. 2020. doi:10.5271/sjweh.3876

13. Gu W. Analysis of the Influence of Geographical Environment on Chinese Food Culture Tourism Resources. Tour Manag Res. 2017;10:29.

14. Hu Y. Study on Ningbo Food Culture. Ningbo university; 2011.

15. Hong Y. Consumer demand, consumer power, consumer economy and economic growth. China's Econ Prob. 2013;1:3-8.

16. Wu J. Investigation of Fishermen's Survival Situation in Zhejiang Province and Analysis of Countermeasures-Taking Wenzhou, Taizhou, Ningbo and Zhoushan as Examples. Chinese Market. 2016;51:69-72.

17. Behroozy A, Keegel TG. Wet-work exposure: a main risk factor for occupational hand dermatitis. Saf Health Work. 2014;5(4):175-180. doi:10.1016/j.shaw.2014.08.001

18. Caroe TK, Ebbehoj NE, Bonde JPE, Flachs EM, Agner T. Hand eczema and wet work: dose-response relationship and effect of leaving the profession. Contact Dermatitis. 2018;78(5):341-347. doi:10.1111/cod.12934

19. Meding B, Anveden Berglind I, Alderling M, Lindahl G, Wrangsjo K. Water exposure-challenging differences between occupations. Contact Dermatitis. 2016;74(1):22-28. doi:10.1111/ $\operatorname{cod} .12479$
Risk Management and Healthcare Policy

\section{Publish your work in this journal}

Risk Management and Healthcare Policy is an international, peerreviewed, open access journal focusing on all aspects of public health, policy, and preventative measures to promote good health and improve morbidity and mortality in the population. The journal welcomes submitted papers covering original research, basic science, clinical \& epidemiological studies, reviews and evaluations,

\section{Dovepress}

guidelines, expert opinion and commentary, case reports and extended reports. The manuscript management system is completely online and includes a very quick and fair peer-review system, which is all easy to use. Visit http://www.dovepress.com/testimonials.php to read real quotes from published authors. 